\title{
Perceived Environmental Uncertainty for Startups: A Note on Entrepreneurship Research from an Indian Perspective
}

\author{
Susmita Ghosh, Bhaskar Bhowmick, and Kalyan Kumar Guin
}

\author{
"Entrepreneurship is "risky" mainly because so few of the") \\ so-called entrepreneurs know what they are doing. \\ Peter F. Drucker (1909-2005) \\ Author and management consultant
}

\begin{abstract}
In an entrepreneurship environment, understanding uncertainty is critical to startups because it is directly related to the context of decision making. In an emerging country such as India, uncertainties are more predominant due to the very nature of the emerging country, which is characterized by an underdeveloped institutional setup, a lack of protection for legal and intellectual property rights, underdeveloped factor markets, and high transaction costs. In this article, a systematic review of the existing literature on environment and uncertainty in an entrepreneurial, emerging-economy context identifies a gap of a new scale for perceived environmental uncertainty. Three primary contributions are made by this research. First, a literature review for existing uncertainty scales and their evaluation in the context of emerging countries is provided. Second, the research identifies a gap in the uncertainty measurement literature that is relevant to emerging economies. Finally, this study proposes a future research scope that can bridge the identified gap by exploring the factors of uncertainty in emerging countries.
\end{abstract}

\section{Introduction}

"Uncertainty" is currently one of the most important research areas in the management and entrepreneurship literature (Verdu et al., 2012) because it restricts the entrepreneurs from taking entrepreneurial actions such as new product development, entry into new market, etc. (McMullen \& Shepherd, 2006).In emerging countries, uncertainty takes on even greater importance because the entrepreneurial environment is often accompanied by opaque and bureaucratic legal systems that fail to protect intellectual property rights and other commercial interests. In India in particular, social, economic, and political shifts following discontinuities have made the situation even more complex (Peng, 2001; Child \& Tse, 2001), as described in Box 1.

The term "uncertainty" has sometimes been used interchangeably with "risk" in the literature. However, the uncertainty construct and its closest companion, risk, are discussed by Knight (1921), and LeRoy and Singell
(1987), as two possibilities out of three distinct unknown-outcome situations. In the first situation, a priori probability can be assigned by deducing a categorization of instances (e.g., outcome probabilities associated with rolling dice), and the second situation states that statistical probabilities can be assigned with empirical evaluation of relative frequencies (e.g., life expectancy probabilities calculated by life insurance companies). The third situation occurs when there is no valid basis for classifying instances. Knight (1921) defines the first two situations as risk and the third one as uncertainty. LeRoy and Singell (1987) extend the situation of uncertainty to the case of assigning subjective probability to the unknown outcome. Therefore, uncertainty should be studied based on the different components of the environment and not the environment as a whole (Miles \& Snow, 1978), to interpret its real contribution to decision making. Uncertainties are firm specific, they may be perceived uniquely by the top management of an organization, and they may take different strategic actions to cope with them (Starbuck, 1976). 


\title{
Perceived Environmental Uncertainty for Startups
}

\author{
Susmita Ghosh, Bhaskar Bhowmick, and Kalyan Kumar Guin
}

This environmental uncertainty has direct implications on startups and their decision making, so the important question is how to conceptualize and measure this uncertainty. Previous researchers in this domain have tried to identify and quantify the various environmental factors that contribute to uncertainty (e.g., Lawrence \& Lorsch, 1967; Duncan, 1972; Miles \& Snow, 1978; Milliken, 1987). However, most of this research has been conducted in developing countries, and the uncertainty conceptualization in emerging countries may be different. Emerging countries are known for their institutional voids in legal and administrative systems in relation to intellectual property rights, etc. Hence, there is a gap in the literature concerning measurement of perceived environmental uncertainty.

This study introduces the background literature relating to environment and uncertainty, and it explores the existing scales and their limitations in measuring environmental uncertainty. Then, it explains the operationalization of perceived environmental uncertainly in an emerging country context. The last section concludes that the existing uncertainty scale must be examined and modified, including factor identification and related measures of environmental uncertainty for startups in emerging countries.

\section{Literature Review}

The literature was reviewed systematically using several strategies to locate relevant studies. First, we searched the following databases: Emerald Insights, EBSCO, Science Direct, Wiley Online Library, and Google Scholar. In each of these databases, we used the following search terms: "environmental uncertainty", "entrepreneurial firms", "start-up firms", "emerging country", and "India". Second, we conducted manual searches of journals that publish research on entrepreneurship: Academy of Management Journal, Journal of Business Venturing, Entrepreneurship Theory and Practices, Journal of Small Business Management, and Strategic Management Journal.

In our search of the environmental uncertainty literature we found 21 studies that dealt with the uncertainty construct towards defining and specifying the meaning of the term in relation to other constructs in the organization theory domain. Multiple definitions of uncertainty were defined in seven studies, whereas six studies discussed various types and sources of uncertainty. The relationship between uncertainty and other constructs and variables in the entrepreneurship environment literature was covered in 41 studies.
Box 1. Historical sources of entrepreneurial uncertainty in India

Since achieving independence in 1947, India has seen four major discontinuities that resulted from different politico-economic reasons (Sibal, 2012). Beginning with its first five-year economic plan, in the first phase (1951-1965), the independent Indian economy saw rapid industrialization guided by the heavy investment from the government coffers to make the nation industrially self sustained. The larger industries were more or less controlled by public sector firms, which created uncertainty of sector choice and opportunity recognition for small and startup firms. The second phase (1965-1981) of the Indian economy was "a period of incoherence between micro- and macro-economic developments" due to political and leadership instability in the country, followed by "anemic growth and extreme volatility" (Sibal, 2012), due to a mismatch between expectation and result in the agricultural output, which led to uncertainty in demand and infrastructure support. In the third phase (1981-1991), the Indian economy succumbed to a fiscally induced debt crisis, which was due to recession in the international market, and which necessitated financing from the International Monetary Fund. The crisis "helped usher in change that seemed impossible merely one or two years earlier" (Sibal, 2012), In the fourth phase (post 1991), the Indian economy saw "a greater separation between the government and the economy" (Sibal, 2012). Although, the state continues to run a number of enterprises, "India took major strides in permitting enterprises to react to market signals but maintained control over India's exposure to the global economy by retaining a tightly controlled capital account" (Sibal, 2012). The current phase is characterized by uncertainty in international competition and increased consumer choices due to globalization, which are the result of the opening up of the economy in 1991 and the entry of international competitors in sectors such as aviation, banking, and manufacturing. Thus, the historical changes in India's economic scenario and the complex linkages of socio-economic, technological, and financial elements have created uncertainty. Startup firms in such an uncertain environment are exposed to resource scarcity, abundant opportunities, and rivalry competitions due to less developed and more costly external environmental factors (Uhlenbruck et al., 2003). Therefore, identifying the factors responsible for environmental uncertainty, as perceived by Indian startups, better positions entrepreneurs to seek opportunities, gain competitive advantage, and pursue better performance. 


\title{
Perceived Environmental Uncertainty for Startups
}

\author{
Susmita Ghosh, Bhaskar Bhowmick, and Kalyan Kumar Guin
}

Our search also identified 26 studies measuring the definitional components of perceived environmental uncertainty and external environmental components related to uncertainty. In these studies, uncertainty and its related measures have been linked to different conceptualizations of environment, such as internal and external environments.

Our search for literature relating to environmental uncertainty in entrepreneurial firms or startup firms identified six studies. These studies empirically related the startup uncertainty with technology diffusion, competition, innovation, and entrepreneurial action. Typically, these studies used data from the United Kingdom, Sweden, or other developed countries.

Our search for literature on environmental uncertainty, entrepreneurial firms or startup firms, and emerging countries identified eight studies. These studies related to market opportunity, financial shocks, internationalization, and other growth strategies. The databases used in these studies related to various emerging countries, including Chile, Mexico, Hong Kong, Philippines, Indonesia, Malaysia, South Africa, and South Korea.

Finally, our search for literature on environmental uncertainty, entrepreneurial firms or startup firms, and India identified three studies. These studies relate uncertainty with internationalization, business-to-business market relations, and financial opportunities from an Indian perspective, primarily within the information technology domain, the beverage industry, and business-to-business contexts.

None of the studies replicated the results in an Indian context using quantitative techniques for statistically verifying the relationships and reconfirming the uncertainty measures.

\section{Environment}

Environment has been conceptualized in the literature as a multi-dimensional construct (Lawrence \& Lorsch, 1967; Duncan, 1972); as a total entity composed of social and physical factors that actively contributes to decision making in an organization (Lawrence \& Lorsch, 1967; Duncan, 1972); and as forces that potentially affect the performance of an organization (Porter, 1980). Duncan segmented environment based on the relevance of the social and physical factors comprising it. These factors provide necessary information related to their behavioural characteristics for decision making in an organization. Scott (1987) explained these factors as resource pools and information sources of competitors, potential markets, and regulators. Environmental segments, as discussed by Duncan (1972), Lawrence and Lorsch (1967), and Rice (1963) can be internal and external. The internal environment deals with the interaction between an individual within an organization and the interpersonal relationships between members of an organization. The external environment includes groups, institutions, or individuals outside the boundary of the organization. For example, components of the external environment are socio-political, international, and economic elements, as well as technology, customers, and suppliers (Scott, 1987). Environment has also been discussed by researchers (e.g., Adomako \& Danso, 2014; Suarez, 2014; Schultz et al., 2010; Grewal et al., 2013) as having an influence on firm strategy, process, and performance.

We identified two different dimensions of the environment in the literature: the static-dynamic dimension and the simple-complex dimension (Emery \& Trist, 1965; Thompson, 1967; Terreberry, 1968).The dimension of the environment known as simple-complex dimension deals with the number of factors involved in decision making (Duncan, 1972). The organization's diversified activities and their degree of heterogeneity is caused by environmental complexity (Aldrich, 1979). Smart and Virtinskey (1984) proposed that one important dimension of environment is its degree of stability, which is in accordance with Duncan's (1972) view. Duncan proposed that the dynamic dimension of environment deals with the factors of decision making that are changing continually. The dynamism in the environment brings a continuous change in the factors that help organization's make decisions. This changing nature of the factors creates difficulty in availing relevant information that is important for decision making in an organization. Due to the dynamism in the environment, organizations should be able to adapt themselves continuously with the changing environment (Duncan, 1972). The related concept of environmental velocity has been recognized as similar to the dynamic nature of the environment due to the change in the rate and direction of the factors such as technology, regulation, demand, and competition (Bourgeois \& Eisenhardt, 1988). McCarthy and colleagues (2010) identified that velocity can be categorized as simply high or low, and its different patterns affect the organizations.

The simple-complex dimension and static-dynamic dimension have been identified as the sources of uncertainty in environment literature. However, Mintzberg (1979) extended the list with the concept of environmental hostility being another source of uncertainty; 


\title{
Perceived Environmental Uncertainty for Startups
}

\author{
Susmita Ghosh, Bhaskar Bhowmick, and Kalyan Kumar Guin
}

the dimension of munificence and hostility is thus added to the earlier dimensions of static-dynamic and simple-complex as sources of uncertainty. Environmental munificence can be measured by the availability of labour, competitive hostility, and the business cost (Anatan \& Radhi, 2007). Changes in the environmental components (e.g., competition, customers, technology) and the complex interconnections among them create environmental turbulence (Emery \& Trist, 1965), which initiates environmental uncertainty. Managers or decision units of an organization perceive uncertainty related to these different components of the environment.

\section{Conceptualization of uncertainty}

As, the previous sections have shown, a substantial amount of research has focused on an organization's environment, and in most of the studies, uncertainty was the central construct (e.g., Downey \& Slocum, 1975; Duncan, 1972; Emery \& Trist, 1965; Jauch \& Kraft, 1986). A discussion of uncertainty is more pertinent when the decision making is dependent on the future state of the environment, because the future state of it, or the effect of any action based on that decision, is not known.

Environmental uncertainty has multiple definitions (Liao \& Gartner, 2006) in the literature, including the unknown probability of outcome (Knight 1921), hesitancy and indecisiveness (Casson, 1982), a lack of information related to environmental components for decision making (Duncan, 1972), "an individual's perceived inability to predict (an organization's environment) accurately" (Milliken, 1987; Cyert \& March,1963; York \& Venkatraman, 2010), the availability of choice (Child, 1972), a complex combination of environmental components (Galbraith, 1973), and an environmental state (Aldrich, 1979). The inability to predict outcome may be rooted in the availability of information, processing the information toward meaningful knowledge, or simply predicting the final outcome of a decision. Further review of the environmental uncertainty literature suggested that the uncertainty construct has evolved from two theories: i) contingency theory (March \& Simon, 1958; Thompson, 1967; Lawrance \& Lorsch, 1967; Aldag \& Storey, 1975; Starbuck, 1976), which focuses on interpreting the environment and focusing on fitting the organization to the environment and ii) perceptual theory (Duncan, 1972; Child, 1972; Downey \& Slocum, 1975; Starbuck, 1976), which relates uncertainty to process-oriented learning or interpreting and noticing the environment and accessing its real meaning.
Although there still remains a conflict between the significant effects of objective or subjective environment on organizational performance, it is believed that perception mediates between the objective environment to make a meaning of it and take necessary action (Terborg, 1981; Jauch \& Kraft, 1986). Milliken (1987) tried to aggregate these two concepts and proposed three types of perceived environmental uncertainty: state, effect, and response. State uncertainty is experienced when the changing nature of the environmental factors are unpredictable; effect uncertainty deals with an individual's ability to predict the impact of changing environmental factors on the firm; and response uncertainty arises from a lack of decision-making ability in the firm's decision unit. Galbraith's (1973) earlier work is consistent with Milliken's view that each dimension of uncertainty should be investigated independently. However, there are currently no psychometric measurements for any of these three types of uncertainty (Ashill \& Jobber, 2010).

The environmental uncertainty construct is further differentiated by researchers (e.g., Duncan 1972; Jauch et al., 1980; Khandwalla, 1977; Tosi \& Slocum, 1984) according to the sources of uncertainty. Miles and Snow (1978) posited that defining uncertainty broadly as "environmental uncertainty" is not sufficient; it is important to identify and measure the various components of the firm's environment that acts as source of uncertainty for the firm. These environmental components (i.e., customer, competitor, supplier, market, technology, government, and resource) differentially affect the operational and strategic decisions of a firm (Song \& Weiss, 2001; Matthews \& Scott, 1995). An entrepreneurial firm's exploitation of the scale of opportunities depends on the manifested or perceived environmental uncertainty in the environment, whereas an entrepreneur's expertise moderates this relationship (McKelvie, 2011). This study thus focuses on identifying and measuring issues of perceived environmental uncertainty for startups.

\section{Measures of perceived environmental uncertainty}

Lawrence and Lorsch's (1967) method for measuring the uncertainty of an organization was a nine-item Likert scale with questions relating to three sub-scales and three sub-environments: marketing, manufacturing, and research. Each of the respondents is asked to answer three questions about each of the sub-environments, from which uncertainty scores for each sub-environment and a total uncertainty score can be calculated (Gerloff et al., 1991). However, Lawrence and Lorsch's scale was assessed by several researchers, who 


\title{
Perceived Environmental Uncertainty for Startups
}

\author{
Susmita Ghosh, Bhaskar Bhowmick, and Kalyan Kumar Guin
}

reported some limitations. Milliken (1987) suggested that the scale does not appropriately assess the general environment of the firm. Tosi and colleagues (1973) reported low sub-scale scores, marginal reliability, low correlation between the sub-scale and total uncertainty scores. Downey, Hellriegel, and Slocum (1975) tested the reliability and validity of the scale and reported that the scales are reliable after modification, but they were unable to find any correlation between the total uncertainty and the sub-scale scores, even after modification. They raised the questions: "Is perceived environmental uncertainty most usefully considered as unidimensional or multidimensional?" and "Is perceived environmental uncertainty most usefully operationalized through a summative approach or by some unitary process?"

The perceived environmental uncertainty scale developed by Duncan (1972) tried to measure the environmental characteristics that contribute a perception of uncertainty for decision makers (Gerloff et al., 1991) on the basis of lack of information, lack of knowledge, or inability to assign probabilities. Duncan investigated 22 decision groups using a 12-item uncertainty scale and concluded that environmental complexity and dynamism impacts the perception of environmental uncertainty. Milliken (1987) reviewed the uncertainty scale developed by Duncan and noted that Duncan's conceptualization of perceived environmental uncertainty does not follow the traditional understanding of component-level uncertainty. He looks at uncertainty as the perceptual inability to access information, arrive at decision outcomes, and assign probability. Downey and colleagues (1975) attempted to assess Duncan's uncertainty scale and posited that the reliability criteria are problematic. Other researchers performed several studies using Duncan's scale and reported that conceptualizing, interpreting, and generalizing the results of a study using Duncan's scale was difficult because the uncertainty definition in Duncan's scale has been conceptualized in a variety of forms (i.e., from predictability to controllability)(Lindsay \& Rue, 1980; Smart \& Virtinskey, 1984; Dwyer \& Welsh, 1985; Buchko, 1994). Others tried to test the measurement properties of both Lawrence and Lorsch's and Duncan's scales and reported significantly weak results and low reliability (Milliken, 1987; Tosi et al., 1973; Downey et al., 1975). Validation of both the Lawrence and Lorsch's and Duncan's scales using "objective measures of environmental volatility" (Tosi et al., 1973; Downey et al., 1975; Buchko, 1994) were insignificant and gave unsuccessful results. Other studies using Duncan's scale (e.g., McCabe, 1990; Anderson \& Kida, 1985; Koberg \& Ungsen,
1987; Brown \& Schwab, 1984), reported that it was difficult to generalize their results using Duncan's scale. Thus, next-generation researchers tried to change their focus from the organization's point of view to the perspective of the external environment, as will be discussed next.

Continuous debate and evaluation of the existing scales questioning their reliability and validity inspired Miles and Snow (1978) to create a new scale for capturing perceived environmental uncertainty. They developed a measure of uncertainty containing 25 items with 6 subscales related to suppliers, competitors, customers, financial markets, government and regulatory agencies, and unions. The instrument consists of seven-point Likert scale using predictable and unpredictable dimensions. Ireland, Hitt, Bettis, and de Porras (1987) performed a reliability test on the scale and its sub-scales developed by Miles and Snow (1978) and found that the reliability was adequate. Buchko (1994) supported this view and explained that the measurement properties of the scale showed internal consistency but the stability of the scale gave inadequate results as obtained from low test-retest correlations over time.

Miller (1992) proposed a perceived environmental uncertainty scale based on uncertainty in the general environment, the industry environment, and the firm-specific environment. The scale consists of 35 items with 6 sub-scales following seven-point Likert scales with predictable and unpredictable dimensions. Werner, Brouthers, and Brourthers (1996) assessed the scale developed by Miller (1993) and reported high internal consistency with samples from manufacturing and service firms. They raised the issue that the subsets of Miller's scale items were "multiple indicators of factors which could be empirically distinguished from one another" (Werner et al., 1996). This finding contradicted the argument made by Miller (1993) that there exists a complex inter-correlation among environmental uncertainty (Miller, 1997). Song and Weiss (2001) commented that an aggregated measure of uncertainty has little impact and hence posited that identifying the uncertainty scale of a specific component of environment may be useful. They introduced a perceived technological uncertainty scale consisting of six items on a 10-point Likert scale. Leug and Borisov (2014) studied the association between the measures of archival environmental uncertainty - understanding of the environment based on historical data - and perceived environmental uncertainty. They found that measures of perceived environmental uncertainty are effective for scanning and decision making, whereas measures of 


\title{
Perceived Environmental Uncertainty for Startups
}

\author{
Susmita Ghosh, Bhaskar Bhowmick, and Kalyan Kumar Guin
}

archival environmental uncertainty are effective for evaluating performance.

The conceptualization and operationalization of uncertainty has direct impact on startup firms. This relationship can be traced back to Schumpeter's (1974) idea of stressed innovation with uncertainty as discussed by Knight (1921) and Brouwer (2000). Research has also suggested that perceptions of uncertainties are different in manufacturing and service firms at the level of their innovation (Freel, 2005).The uncertainty perception by startup firms directs inverse linking of strategic and operational planning towards bringing their innovation into product development and marketing activities (Matthews \& Scott, 1995).

\section{Operationalization in Emerging Countries}

The above discussion is based on research into measures of environmental components related to uncertainty that have been developed extensively for large firms in emerging countries (e.g., Aldrich, 1979; Boulton et al. 1982; Duncan, 1972; Hambrick, 1983; Jauch \& Kraft, 1986; Pfeffer \& Salancik, 1978). This phenomenon has been largely ignored for startups in an emerging country context. Thus, this study proposes that it is important to identify and measure the environmental components that act as sources of uncertainty for startup firms in emerging countries.

The environment itself is "neither certain nor uncertain" (Downey \& Slocum, 1975) because certainty and uncertainty of an environment is perceived by the firms themselves and are not same for all firms (Downey \& Slocum, 1975; Pfeffer \& Salancik, 1978,). An emerging country perspective offers a substantive context to perceive uncertainty by small and large firms. Startups are exposed to these uncertainties more critically than large firms due to lack of resources, expertise, and information sources. Emerging economies are characterized by high population density, low per capita gross domestic product, and high rates of unemployment (Todd et al., 2007). These factors have direct or indirect impacts on product- or market-related uncertainties for all types of firms. Emerging countries also experience volatile inflation rates, intermittent financial crises, and high dependence on imports (Todd et al., 2007). The impact of a sudden economic crisis leads to delayed recovery in emerging countries after a sudden change in the external environmental factors (Carrière-Swallow \& Céspedes, 2013), which has a direct implication on the financial uncertainty and market responses.
Emerging economies in general show rapid growth and feature economic liberalization as a primary engine for this growth (Li et al., 2013). Emerging countries are also characterized by an underdeveloped institutional setup, including for example, a lack of legal protection for intellectual property rights, poor law enforcement, a lack of transparency in judicial systems, underdeveloped factor markets, and high transaction and market costs (Wu \& Chen, 2014). These factors lead to uncertainties related to R\&D activities and confusion related to protection of intellectual property rights. Market failure due to underdeveloped institutional support adds to the complexity, with additional burdens coming from bureaucracy and high corruption rates. The lack of stable political structures makes the environment more volatile, leading to development of informal institutional constraints with the prominence of informal networks and personalized exchanges (Tracey \& Phillips, 2011), which have indirect impacts on competitiveness and scaling-up activities. The complexity and dynamism become pertinent to uncertainty in emerging countries due to information asymmetry and imperfections in the market for capital, labour, and products. So, the firms face higher risk and spend more resources searching for information (Meyer et al., 2008).

This economic state of affairs makes uncertainty a key feature of emerging economies. Uncertainty paves or hinders the path to prosperity for entrepreneurs in emerging countries, leading them to innovate and take risk differently than in developed countries (Radas \& Božić, 2009). Thus, we require understanding of the real attributes of uncertainty - at a quantitative level.

\section{Conclusion}

We draw three levels of conclusion as future research scopes concerning perceived environmental uncertainty and its measurement. First, the existing uncertainty scales, as discussed in earlier sections, identify contributions from Lawrence and Lorsch (1967), Duncan (1972), Miles and Snow (1978), and Miller (1997). These scales are related to a firm's functionallevel activities with their inability to predict the future states, effects, and responses due to lack of information and uncertainties specific to components of the firm's environment. This situation creates confusion in decision making and permeates to lower levels of performance.

Second, the discussion on emerging countries and their relevant uncertainties leads us to conclude that meas- 


\section{Perceived Environmental Uncertainty for Startups}

\section{Susmita Ghosh, Bhaskar Bhowmick, and Kalyan Kumar Guin}

urement of uncertainty should be context specific and the sub-scales should include the typical nature of uncertainty perceived by the firms from different domains. The institutional void in emerging country context proposes uncertainty from regulatory and judicial protection functionalities. These influences are again country specific. These dynamisms in the environment have implications on the internal environment of the firm. Although the existing scale covers government, policies, and economies at a high level, it fails to capture the impact of these factors within the scale parameters.

Third, this study identifies a gap in the literature and commits to develop a new scale of perceived environmental uncertainty specifically in the context of an emerging country such as India. This scale will be further examined and verified to generalize it to other emerging countries. This scale will be developed by identifying and exploring factors from existing literature supported through qualitative understanding of the context by practicing entrepreneurs. The new scale would facilitate startups in emerging countries to identify the dominant sources of uncertainties along with the environmental components.

\section{References}

Adomako, S., \& Danso, A. 2014. Regulatory Environment, Environmental Dynamism, Political Ties, and Performance. Journal of Small Business and Enterprise Development, 21(2): 212-230. http://dx.doi.org/10.1108/JSBED-01-2014-0004

Aldag, R. J., \& Storey, R. G. 1975. Environmental Uncertainty: Comments on Objective and Perceptual Indices. Academy of Management Proceedings, 1975(1): 203-205.

http://dx.doi.org/10.5465/AMBPP.1975.4982411

Aldrich, H. 2008. Organizations and Environments. Stanford University Press.

Anatan, L., \& Radhi, F. 2007. The Effect of Environmental Factors, Manufacturing Strategy and Technology on Operational Performance: Study Amongst Indonesian Manufacturers. Jurnal Ekonomi \& Bisnis, 1(3): 119-133.

Anderson, T. N., \& Kida, T. E. 1985. The Effect of Environmental Uncertainty on the Association of Expectancy Attitudes, Effort, and Performance. The Journal of Social Psychology, 125(5): 631-636. http://dx.doi.org/10.1080/00224545.1985.9712037

\section{About the Authors}

Susmita Ghosh is a Research Scholar at Rajendra Mishra School of Engineering Entrepreneurship, Indian Institute of Technology Kharagpur. Currently she is pursuing her doctoral degree in Entrepreneurship, with a research focus on uncertainties in decision making for startups. Her other current research interests include entrepreneurial business incubation and uncertainty in product development.

Bhaskar Bhowmick is an as Assistant Professor at Rajendra Mishra School of Engineering Entrepreneurship, Indian Institute of Technology Kharagpur, India. He completed his $\mathrm{PhD}$ from the Indian Institute of Management Ahmadabad with a specialization in Business Policy. He has thirteen years of industry experience in sales and marketing. His research interests include strategy-sustenance-succession, leadership strategy, and uncertainty in product development, innovation, and entrepreneurship.

Kalyan Kumar Guin is Dean and Professor at the Vinod Gupta School of Management, Indian Institute of Technology Kharagpur, India. He is an alumnus of IIT Kharagpur and Banaras Hindu University in Varanasi, India, and he is a Fellow of the Indian Institute of Management Bangalore. His teaching interests cover marketing and operations management, and he has a special interest in quantitative modelling of strategic issues in management.

Ashill, N. J., \& Jobber, D. 2009. Measuring State, Effect, and Response Uncertainty: Theoretical Construct Development and Empirical Validation. Journal of Management, 36(5): 1278-1308. http://dx.doi.org/10.1177/0149206308329968

Boulton, W. R., Lindsay, W. M., Franklin, S. G., \& Rue, L. W. 1982. Strategic Planning: Determining the Impact of Environmental Characteristics and Uncertainty. Academy of Management Journal, 25(3): 500-509.

http://dx.doi.org/10.2307/256076

Bourgeois, L. J., \& Eisenhardt, K. M. 1988. Strategic Decision Processes in High Velocity Environments: Four Cases in the Microcomputer Industry. Management Science, 34(7): 816-835. http://dx.doi.org/10.1287/mnsc.34.7.816

Brouwer, M. 2000. Entrepreneurship and Uncertainty: Innovation and Competition among the Many. Small Business Economics, 15(2): 149-160.

http://dx.doi.org/10.1023/A:1008147829791

Brown, W. B., \& Schwab, R. C. 1984. Boundary-Spanning Activities in Electronics Firms. IEEE Transactions on Engineering Management, 31(3): 105-111.

http://dx.doi.org/10.1109/TEM.1984.6447517

www.timreview.ca 


\section{Perceived Environmental Uncertainty for Startups}

\section{Susmita Ghosh, Bhaskar Bhowmick, and Kalyan Kumar Guin}

Buchko, A. A. 1994. Conceptualization and Measurement of Environmental Uncertainty: An Assessment of the Miles and Snow Perceived Environmental Uncertainty Scale. Academy of Management Journal, 37(2): 410-425.

http://dx.doi.org/10.2307/256836

Carrière-Swallow, Y., \& Céspedes, L. F. 2013. The Impact of Uncertainty Shocks in Emerging Economies. Journal of International Economics, 90(2): 316-325.

http://dx.doi.org/10.1016/j.jinteco.2013.03.003

Casson, M. 1982. The Entrepreneur: An Economic Theory. Rowman \& Littlefield.

Child, J. 1972. Organizational Structure, Environment and Performance: The Role of Strategic Choice. Sociology, 6(1): 1-22. http://dx.doi.org/10.1177/003803857200600101

Child, J., \& Tse, D. K. 2001. China's Transition and its Implications for International Business. Journal of International Business Studies, 32(1): 5-21.

http://dx.doi.org/10.1057/palgrave.jibs.8490935

Cyert, R. M., \& March, J. G. 2013. A Behavioral Theory of the Firm. Martino Publishing.

Downey, H. K., Hellriegel, D., \& Slocum, J. W. 1977. Individual Characteristics as Sources of Perceived Uncertainty Variability. Human Relations, 30(2): 161-174.

http://dx.doi.org/10.1177/001872677703000205

Downey, H. K., \& Slocum, J. W. 1975. Uncertainty: Measures, Research, and Sources of Variation. Academy of Management Journal, 18(3): 562-578.

http://dx.doi.org/10.2307/255685

Duncan, R. B. 1972. Characteristics of Organizational Environments and Perceived Environmental Uncertainty. Administrative Science Quarterly, 17(3): 313.

http://dx.doi.org/10.2307/2392145

Dwyer, F. R., \& Welsh, M. A. 1985. Environmental Relationships of the Internal Political Economy of Marketing Channels. Journal of Marketing Research, 22(4): 397. http://dx.doi.org/10.2307/3151585

Emery, F. E., \& Trist, E. L. 1965. The Causal Texture of Organizational Environments. Human Relations, 18(1): 21-32. http://dx.doi.org/10.1177/001872676501800103

Freel, M. S. 2005. Perceived Environmental Uncertainty and Innovation in Small Firms. Small Business Economics, 25(1): 49-64. http://dx.doi.org/10.1007/s11187-005-4257-9

Galbraith, J. R. 1969. Organization Design: An Information Processing View. Working Paper No. 425-69. Massachusetts Institute of Technology.

Gerloff, E. A., Muir, N. K., \& Bodensteiner, W. D. 1991. Three Components of Perceived Environmental Uncertainty: An Exploratory Analysis of the Effects of Aggregation. Journal of Management, 17(4): 749-768.

http://dx.doi.org/10.1177/014920639101700408

Grewal, R., \& Dharwadkar, R. 2002. The Role of the Institutional Environment in Marketing Channels. Journal of Marketing, 66(3): 82-97. http://dx.doi.org/10.1509/jmkg.66.3.82.18504

Hambrick, D. C. 1982. Environmental Scanning and Organizational Strategy. Strategic Management Journal, 3(2): 159-174. http://dx.doi.org/10.1002/smj.4250030207
Ireland, R. D., Hitt, M. A., Bettis, R. A., \& De Porras, D. A. 1987. Strategy Formulation Processes: Differences in Perceptions of Strength and Weaknesses Indicators and Environmental Uncertainty by Managerial Level. Strategic Management Journal, 8(5): 469-485.

http://dx.doi.org/10.1002/smj.4250080506

Jauch, L. R., \& Kraft, K. L. 1986. Strategic Management of Uncertainty. Academy of Management Review, 11(4): 777-790. http://dx.doi.org/10.2307/258396

Khandwalla, P. N. 1976. Some Top Management Styles, Their Context, and Performance. Organization and Administrative Sciences, 7(4): 21-51.

Knight, F. H. 1964. Risk, Uncertainty and Profit. Courier Dover Publications.

Koberg, C. S., \& Ungson, G. R. 1987. The Effects of Environmental Uncertainty and Dependence on Organizational Structure and Performance: A Comparative Study. Journal of Management, 13(4): 725-737.

http://dx.doi.org/10.1177/014920638701300412

Lawrence, P. R., \& Lorsch, J. W. 1967. Organization and Environment: Managing Differentiation and Integration. Boston: Division of Research, Graduate School of Business Administration, Harvard University.

Liao, J., \& Gartner, W. B. 2006. The Effects of Pre-venture Plan Timing and Perceived Environmental Uncertainty on the Persistence of Emerging Firms. Small Business Economics, 27(1): 23-40. http://dx.doi.org/10.1007/s11187-006-0020-0

Lindsay, W. M., \& Rue, L. W. 1980. Impact of the Organization Environment on the Long-Range Planning Process: A Contingency View. Academy of Management Journal, 23(3): 385-404. http://dx.doi.org/10.2307/255507

Lueg, R., \& Borisov, B. G. 2014. Archival or Perceived Measures of Environmental Uncertainty? Conceptualization and New Empirical Evidence. European Management Journal, 32(4): 658-671. http://dx.doi.org/10.1016/j.emj.2013.11.004

March, J. G., \& Simon, H. A. 1958. Organizations. Cambridge, MA: Wiley-Blackwell.

Matthews, C. H., \& Scott, S. G. 1995. Uncertainty and Planning in Small and Entrepreneurial Firms: An Empirical Assessment. Journal of Small Business Management, 33(4): 34.

McCabe, D. L. 1990. The Assessment of Perceived Environmental Uncertainty and Economic Performance. Human Relations, 43(12): 1203-1218. http://dx.doi.org/10.1177/001872679004301202

McCarthy, I. P., Lawrence, T. B., Wixted, B., \& Gordon, B. R. 2010. A Multidimensional Conceptualization of Environmental Velocity. Academy of Management Review, 35(4): 604-626.

McKelvie, A., Haynie, J. M., \& Gustavsson, V. 2011. Unpacking the Uncertainty Construct: Implications for Entrepreneurial Action. Journal of Business Venturing, 26(3): 273-292. http://dx.doi.org/10.1016/j.jbusvent.2009.10.004

McMullen, J. S., \& Shepherd, D. A. 2006. Entrepreneurial Action And The Role Of Uncertainty In The Theory Of The Entrepreneur. Academy of Management Review, 31(1): 132-152. http://dx.doi.org/10.5465/AMR.2006.19379628 


\section{Perceived Environmental Uncertainty for Startups}

\section{Susmita Ghosh, Bhaskar Bhowmick, and Kalyan Kumar Guin}

Meyer, K. E., Estrin, S., Bhaumik, S. K., \& Peng, M. W. 2009. Institutions, Resources, and Entry Strategies in Emerging Economies. Strategic Management Journal, 30(1): 61-80.

http://dx.doi.org/10.1002/smj.720

Miles, R. E., \& Snow, C. C. 1978. Organizational Strategy, Structure, and Process. Stanford University Press.

Miller, K. D. 1993. Industry and Country Effects on Managers' Perceptions of Environmental Uncertainties. Journal of International Business Studies, 24(4): 693-714.

http://dx.doi.org/10.1057/palgrave.jibs.8490251

Miller, K. D. 1997. Measurement of Perceived Environmental Uncertainties: Response and Extension. Working Paper. West Lafayette, IN: Krannert Graduate School of Management.

Milliken, F. J. 1987. Three Types of Perceived Uncertainty About the Environment: State, Effect, and Response Uncertainty. Academy of Management Review, 12(1): 133-143. http://dx.doi.org/10.5465/AMR.1987.4306502

Mintzberg, H. 1979. The Structuring of Organizations: A Synthesis of the Research. Prentice-Hall.

Peng, M. W. 2001. The Resource-Based View and International Business. Journal of Management, 27(6): 803-829. http://dx.doi.org/10.1016/S0149-2063(01)00124-6

Pfeffer, J., \& Salancik, G. R. 1978. The External Control of Organizations: A Resource Dependence Perspective. New York: Prentice-Hall.

Porter, M. E. 1980. Competitive Strategy: Techniques for Analyzing Industries and Competitors. Free Press.

Radas, S., \& Božić, L. 2009. The Antecedents of SME Innovativeness in an Emerging Transition Economy. Technovation, 29(6-7): 438-450. http://dx.doi.org/10.1016/j.technovation.2008.12.002

Rice, A. K. 1963. The Enterprise and Its Environment: A System Theory of Management Organization. Tavistock.

Schultz, M. T., Mitchell, K. N., Harper, B. K., \& Bridges, T. S. 2010. Decision Making Under Uncertainty. No. ERDC TR-10-12. Washington, D.C.: Engineer Research and Development Center: U.S. Army Corps of Engineers.

Schumpeter, J. A. 1974. Capitalism, Socialism and Democracy. London: Unwin University Books.

Scott, W. R. 1987. Organizations: Rational, Natural, and Open Systems. Prentice Hall.

Sibal, D. R. 2012. The Untold Story of India's Economy. India: The Next Superpower? IDEAS: 17-22. London School of Economics.

Smart, C., \& Vertinsky, I. 1984. Strategy and the Environment: A study of Corporate Responses to Crises. Strategic Management Journal, 5(3): 199-213.

http://dx.doi.org/10.1002/smj.4250050302

Song, M., \& Montoya-Weiss, M. M. 2001. The Effect of Perceived Technological Uncertainty on Japanese New Product Development. Academy of Management Journal, 44(1): 61-80. http://dx.doi.org/10.2307/3069337
Starbuck, W. H. 1976. Organizations and Their Environments. In M. D. Dunnette (Ed.), Handbook of Industrial and Organizational Psychology: 1069-1124. Chicago: Rand McNally.

Terborg, J. R. 1981. Interactional Psychology and Research on Human Behavior in Organizations. Academy of Management Review, 6(4): 569-576.

http://dx.doi.org/10.5465/AMR.1981.4285691

Terreberry, S. 1968. The Evolution of Organizational Environments. Administrative Science Quarterly, 12(4): 590. http://dx.doi.org/10.2307/2391535

Thompson, J. D. 1967. Organizations in Action: Social Science Bases of Administrative Theory. New York: McGraw-Hill.

Todd, P. R., \& Javalgi, R. (Raj) G. 2007. Internationalization of SMEs in India: Fostering Entrepreneruship by Leveraging Information Technology. International Journal of Emerging Markets, 2(2): 166-180. http://dx.doi.org/10.1108/17468800710739234

Tosi, H., Aldag, R., \& Storey, R. 1973. On the Measurement of the Environment: An Assessment of the Lawrence and Lorsch Environmental Uncertainty Subscale. Administrative Science Quarterly, 18(1): 27-36.

http://dx.doi.org/10.2307/2391925

Tosi, H. L., \& Slocum, J. W. 1984. Contingency Theory: Some Suggested Directions. Journal of Management, 10(1): 9-26. http://dx.doi.org/10.1177/014920638401000103

Tracey, S. L. P., \& Phillips, P. N. 2011. Entrepreneurship in Emerging Markets. Management International Review, 51(1): 23-39. http://dx.doi.org/10.1007/s11575-010-0066-8

Uhlenbruck, K., Meyer, K. E., \& Hitt, M. A. 2003. Organizational Transformation in Transition Economies: Resource-based and Organizational Learning Perspectives. Journal of Management Studies, 40(2): 257-282.

http://dx.doi.org/10.1111/1467-6486.00340

Verdu, A. J., Tamayo, I., \& Ruiz-Moreno, A. 2012. The Moderating Effect of Environmental Uncertainty on the Relationship between Real Options and Technological Innovation in High-Tech Firms. Technovation, 32(9-10): 579-590. http://dx.doi.org/10.1016/j.technovation.2012.06.001

Werner, S., Brouthers, L. E., \& Brouthers, K. D. 1996. International Risk and Perceived Environmental Uncertainty: The Dimensionality and Internal Consistency of Miller's Measure. Journal of International Business Studies, 27(3): 571-587. http://dx.doi.org/10.1057/palgrave.jibs.8490144

Wu, J., \& Chen, X. 2014. Home Country Institutional Environments and Foreign Expansion of Emerging Market Firms. International Business Review, 23(5): 862-872. http://dx.doi.org/10.1016/j.ibusrev.2014.01.004

York, J. G., \& Venkataraman, S. 2010. The Entrepreneur-Environment Nexus: Uncertainty, Innovation, and Allocation. Journal of Business Venturing, 25(5): 449-463. http://dx.doi.org/10.1016/j.jbusvent.2009.07.007 